\title{
乳牛における分娩前の血糖および遊離脂肪酸値と 分娩後の負のエネルギーバランスの関係
}

佐藤 繁 河野充彦 $^{1)}$ 村山勇雄 $^{11}$ 高橋孝幸 $^{11} \quad$ 鈴木利行 $^{11}$

NOSAI宮城事業部、 ${ }^{1)}$ 県南家畜診療センター

\section{Association of Prepartum Blood Glucose and Non-Esterified Fatty Acid and Postpartum Negative Energy Balance in Dairy Cows}

\author{
S. Sato, M. Kohno ${ }^{1)}$, I. Murayama ${ }^{1)}$, T. Takahashi ${ }^{1)}$, T. Suzuki ${ }^{1)}$ \\ The Operation Division and ${ }^{11}$ Ken-nan Livestock Animal Hospital, \\ Miyagi Prefectural Federated Agricultural Mutual Aid Association
}

\begin{abstract}
要 約 分婏前の負のエネルギーバランス（NEB）は胎児の成長に伴う栄養要求の増大や乾物摂取 量の低下と関連があるが、その実態や分娩後のNEBとの関係は知られていない。健康乳牛における分 婏前のNEBと分婏後のNEBとの関係を明らかにする目的で、分婏前 2-0 週の血糖 (GLU) 值と遊離 脂肪酸（NEFA）值を基準としてI〜IVの 4 群に区分し、分娩後の血中成分の推移を検討した。その結 果、GLUは分娭後 2-4 週に I 群（低GLU ・高NEFA）とII群（低GLU ·低NEFA）で、III群（高GLU · 高NEFA）やIV群（高GLU・低NEFA）に比べて低値、NEFAは分婏後 $0-2$ 週と $2-4$ 週にII群とI 群で、IV群に比べて高值を示した。アスパラギン酸アミノトランスフェラーゼ（AST）は分娩後 $0-$ 2 週と 2-4 週にП群で、向群やIV群に比べて高值、 $\gamma$ グルタミルトランスペプチダーゼ（GGT）は 分娩後 2-4 週にI 群で、I群に比べて高值を示した。また、分婏後にはGLUとASTとの間に負の相 関、NEFAとASTおよびGGTとの間に正の相関が認められた。これらのことから、分婏後 $2-4$ 週の NEBは分婏前 $2-0$ 週のNEBと密接な関連があり、また、分姢後のNEBは肝機能と関連のあることが 示唆された。

——ーワード：乳牛、血糖、負のエネルギーバランス（NEB）、遊離脂肪酸、分婏前後
\end{abstract}

家畜臨床誌２8(1):1-6, 2005

ABSTRACT Prepartum negative energy balance (NEB) in dairy cows is caused by the increased demand of energy due to the rapid growth of fetus and decreased feed intake. However, the etiology of prepartum NEB and its association with postpartum NEB are not well understood. This study was conducted to determine the association between pre- and postpartum NEB in dairy cows. Cows were allocated into four groups based on the blood glucose (GLU) and nonesterified fatty acid (NEFA) profiles at 2-0 wk prior to calving: Group I ( $n=23$; low GLU, high NEFA); Group II ( $n=30$; low GLU, low NEFA); Group III $(n=15$; high GLU, high NEFA) and 
Group IV ( $\mathbf{n}=24$; high GLU, low NEFA). GLU showed lower levels in Groups I and II compared to Groups III and IV at 2 to 4 wk after parturition, whereas NEFA was higher in Groups I and II compared to Group IV at 0-2 and 2-4 wk after parturition. Aspartate aminotransferase (AST) in Group II was higher than that in Groups III and IV at 2-4 wk postpartum, and g-glutamyl transferase (GGT) was higher in Group I compared to Group II at 2-4 wk postpartum. In total, we found a negative correlation between GLU and AST and a positive correlation among NEFA, AST and GGT after parturition. These results suggest that NEB at $2-4$ wk postpartum is closely associated with NEB at 2-0 wk prepartum, and high postpartum NEB is associated with decreased liver function.

Key Words : dairy cows, glucose, negative energy balance (NEB), non-esterified fatty acid (NEFA), periparturient periods. -Jpn. J. Vet. Cinics 28(1):1-6, 2005

\section{緒 言}

乳牛の妊娠末期には胎児や子宮の栄養要求が増大する のに対して乾物掑取量が低下し、分婏後には泌乳のため に栄養要求が増大するのに対して乾物摃取量の増加が遅 延する $[1,6]$ 。エネルギーの要求量と摂取量の不均 衡に起因した負のエネルギーバランス（NEB）は、脂 肪肝やケトーシスなどの周産期疾患の発生 $[10,11]$ 、 その後の泌乳量や発情回帰とも関連がある $[9]$ 。妊娠 末期にエネルギーが不足すると体脂肪が動員されて遊離 脂肪酸（NEFA）が高值を示す $[14 ， 17]$ と報告されて いる。すでに著者ら [16］は、分婏後にケトーシスを発 症した乳牛では健康牛に比べて分婏前 $2-0$ 週にNEFA が高值を示すこと、また、臨床的異常がみられない健康 牛でも分婏後に血糖（GLU）が低值でNEFAが高值を 示すものが多いことを認めた。分婏前のNEBは胎児の 成長に伴う栄盖要求の増大、エネルギー不足や乾物摂取 量低下に起因したものと考えられるが、その実態拉よび 分婏後のNEBとの関係は知られていない。

今回、分婏前におけるNEBの実態拉よび分婏前の NEB と分婏後のNEBとの関係を明らかにする目的で、 健康乳牛における分婏前の血中成分および分婏前の GLU值とNEFA值別に分婏後に扔ける血中成分の推移 を検討した。

\section{材料および方法}

供試牛群および供試牛：供試牛群は宮城県南地域の36 戸で、飼養形態は全てタイストール慗留、飼料は分離給 与あるいは混合飼料給与が行われていた。牛群検定農家 （8戸）における305日補正乳量は8,300〜11,500kgであっ た。供試牛は分婏前14-3 日の経産乳牛で、分婏前後に 臨床的異常が認められなかった92頭（各戸 $2 〜 4$ 頭）で

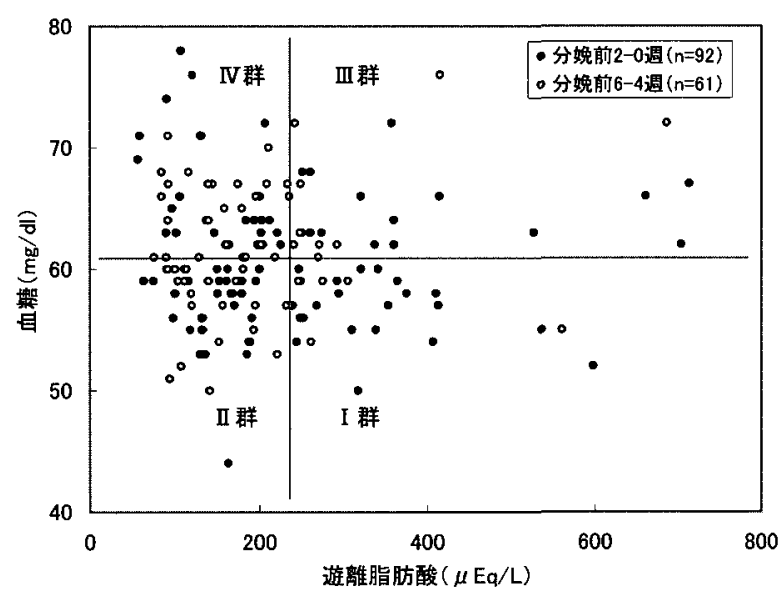

図 1. 健康乳牛の分婏前における血糖および遊離脂肪酸 值の分布

ある。供試牛は分婏前14〜3 日のGLUとNEFAの平均 值 $(61 \mathrm{mg} / \mathrm{d} \mathrm{l}$ と $236 \mu \mathrm{Eq} / \mathrm{L})$ を基準として I 〜 IVの 4 群 に区分した（図 1)。I群（23頭）はGLUが平均値より 低值でNEFAが平均値より高値（低GLU ・高NEFA）、 I群（30頭）はGLUが低值でNEFAも低值（低GLU ・ 低NEFA）、血群（15頭）はGLUが高值でNEFAも高值 (高GLU・高NEFA)、IV 群（24頭）はGLUが高值でNE FAが低值（高GLU・低NEFA）を示したものである。

採血および血液生化学検查：採血は血清分離用プレイ ン採血管と血糖測定用フッ化ナトリウム加採血管を用い、 原則として分婏前 $6 \sim 4$ 週、分婏前 $2 \sim 1$ 週、分婏後 2 週以内抢よび分婏後 $3 \sim 4$ 週に実施した。採取した血液 は 2 時間以内に血清や血漿を分離し、 $-20^{\circ} \mathrm{C} て ゙$ 凍結保存 後に血中成分の測定に供した。血液生化学検査は自動分 析装置 (デイメンションRxL，デイドベーリング，東京） を用いて、GLU、NEFA、総コレステロール（TCHO）、 尿素窒素 (BUN)、総タンパタ (TP)、アルブミン

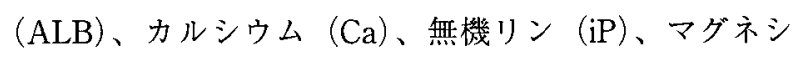


表 1. 健康乳牛の分娩前 $2-0$ 週における血糖および遊離脂肪酸值別"の血中成分值の推移

\begin{tabular}{|c|c|c|c|c|c|c|c|c|c|c|c|c|c|c|}
\hline \multirow[b]{2}{*}{ 項 目 } & \multirow[b]{2}{*}{ （単位） } & & \multicolumn{4}{|c|}{ 分娩前 $2-0$ 週 } & \multicolumn{4}{|c|}{ 分娩後 $0-2$ 週 } & \multicolumn{4}{|c|}{ 分娩後 $2-4$ 週 } \\
\hline & & & $\begin{array}{c}\mathrm{I} \text { 群 } \\
(\mathrm{n}=23)\end{array}$ & $\begin{array}{c}\text { I 群 } \\
(\mathrm{n}=30)\end{array}$ & $\begin{array}{c}\text { III 群 } \\
(\mathrm{n}=15)\end{array}$ & $\begin{array}{c}\text { IV 群 } \\
(\mathrm{n}=24)\end{array}$ & $\begin{array}{c}\mathrm{I} \text { 群 } \\
(\mathrm{n}=11)\end{array}$ & $\begin{array}{c}\text { II 群 } \\
(\mathrm{n}=16)\end{array}$ & $\begin{array}{c}\text { III 群 } \\
(\mathrm{n}=7)\end{array}$ & $\begin{array}{c}\mathrm{IV} \text { 群 } \\
(\mathrm{n}=15)\end{array}$ & $\begin{array}{c}\mathrm{I} \text { 群 } \\
(\mathrm{n}=10)\end{array}$ & $\begin{array}{c}\text { II 群 } \\
\langle\mathrm{n}=12\rangle\end{array}$ & $\begin{array}{c}\text { III 群 } \\
(\mathrm{n}=7)\end{array}$ & $\begin{array}{c}\text { V 群 } \\
(\mathrm{n}=10)\end{array}$ \\
\hline 血 糖 & $(\mathrm{mg} / \mathrm{dl})$ & $\begin{array}{l}\mathrm{M} \\
\mathrm{SD}\end{array}$ & $\begin{array}{r}57 \\
3\end{array}$ & $\begin{array}{r}57 \\
3\end{array}$ & $\begin{array}{c}65^{\mathrm{b} d \mathrm{~d})} \\
3\end{array}$ & $\begin{array}{l}66^{\mathrm{bjd}} \\
5\end{array}$ & $\begin{array}{r}48 \\
8\end{array}$ & $\begin{array}{r}47 \\
9\end{array}$ & $\begin{array}{r}52 \\
3\end{array}$ & $\begin{array}{r}50 \\
6\end{array}$ & $\begin{array}{l}46 \\
10\end{array}$ & $\begin{array}{r}48 \\
5\end{array}$ & $\begin{array}{c}56^{\text {a)d) }} \\
4\end{array}$ & $\begin{array}{c}54^{c)} \\
7\end{array}$ \\
\hline 遊離脂肪酸 & $(\mu \mathrm{Eq} / \mathrm{L})$ & $\begin{array}{l}\mathrm{M} \\
\mathrm{SD}\end{array}$ & $\begin{array}{l}360 \\
143\end{array}$ & $\begin{array}{r}151 \\
37\end{array}$ & $\begin{array}{l}403^{\mathrm{d})} \\
167\end{array}$ & $\begin{array}{c}152^{b)} \\
55\end{array}$ & $\begin{array}{l}667 \\
497\end{array}$ & $\begin{array}{l}662 \\
280\end{array}$ & $\begin{array}{l}672 \\
417\end{array}$ & $\begin{array}{l}443^{\mathrm{c})} \\
215\end{array}$ & $\begin{array}{l}565 \\
258\end{array}$ & $\begin{array}{l}481 \\
210\end{array}$ & $\begin{array}{l}470 \\
296\end{array}$ & $\begin{array}{l}362^{\mathrm{a})} \\
164\end{array}$ \\
\hline 稀コレステロール & $(\mathrm{mg} / \mathrm{dl})$ & $\begin{array}{c}\mathrm{M} \\
\mathrm{SD}\end{array}$ & $\begin{array}{l}88 \\
23\end{array}$ & $\begin{array}{r}106 \\
30\end{array}$ & $\begin{array}{r}104 \\
30\end{array}$ & $\begin{array}{r}104 \\
46\end{array}$ & $\begin{array}{l}95 \\
31\end{array}$ & $\begin{array}{r}101 \\
32\end{array}$ & $\begin{array}{r}118 \\
52\end{array}$ & $\begin{array}{r}110 \\
22\end{array}$ & $\begin{array}{r}132 \\
41\end{array}$ & $\begin{array}{r}141 \\
37\end{array}$ & $\begin{array}{r}147 \\
31\end{array}$ & $\begin{array}{r}154 \\
28\end{array}$ \\
\hline 尿素窒素 & $(\mathrm{mg} / \mathrm{dl})$ & $\begin{array}{l}\mathrm{M} \\
\mathrm{SD}\end{array}$ & $\begin{array}{r}10.0 \\
3.1\end{array}$ & $\begin{array}{c}12.7^{\mathrm{a})} \\
4.7\end{array}$ & $\begin{array}{r}10.6 \\
2.8\end{array}$ & $\begin{array}{r}11.0 \\
3.2\end{array}$ & $\begin{array}{l}9.9 \\
5.5\end{array}$ & $\begin{array}{r}10.5 \\
3.4\end{array}$ & $\begin{array}{r}10.0 \\
4.1\end{array}$ & $\begin{array}{l}9.8 \\
3.2\end{array}$ & $\begin{array}{r}10.4 \\
2.5\end{array}$ & $\begin{array}{l}9.4 \\
4.1\end{array}$ & $\begin{array}{r}10.1 \\
2.4\end{array}$ & $\begin{array}{r}10.3 \\
3.2\end{array}$ \\
\hline 総タンパク & $(\mathrm{g} / \mathrm{dl})$ & $\begin{array}{l}\mathrm{M} \\
\mathrm{SD}\end{array}$ & $\begin{array}{l}7.3 \\
0.9\end{array}$ & $\begin{array}{l}7.4 \\
0.7\end{array}$ & $\begin{array}{l}7.3 \\
0.6\end{array}$ & $\begin{array}{l}7.1 \\
0.7\end{array}$ & $\begin{array}{l}7.5 \\
0.7\end{array}$ & $\begin{array}{l}7.4 \\
0.9\end{array}$ & $\begin{array}{l}7.6 \\
0.8\end{array}$ & $\begin{array}{l}7.2 \\
0.7\end{array}$ & $\begin{array}{l}7.8 \\
0.7\end{array}$ & $\begin{array}{l}7.6 \\
0.8\end{array}$ & $\begin{array}{l}8.0 \\
1.0\end{array}$ & $\begin{array}{l}7.7 \\
0.7\end{array}$ \\
\hline アルブミン & $(\mathrm{g} / \mathrm{dl})$ & $\begin{array}{l}\mathrm{M} \\
\mathrm{SD}\end{array}$ & $\begin{array}{l}3.8 \\
0.4\end{array}$ & $\begin{array}{l}3.8 \\
0.3\end{array}$ & $\begin{array}{l}3.8 \\
0.3\end{array}$ & $\begin{array}{l}3.7 \\
0.4\end{array}$ & $\begin{array}{l}3.7 \\
0.3\end{array}$ & $\begin{array}{l}3.8 \\
0.4\end{array}$ & $\begin{array}{l}3.8 \\
0.3\end{array}$ & $\begin{array}{l}3.7 \\
0.3\end{array}$ & $\begin{array}{l}3.7 \\
0.6\end{array}$ & $\begin{array}{l}3.6 \\
0.4\end{array}$ & $\begin{array}{l}4.0 \\
0.5\end{array}$ & $\begin{array}{l}3.9 \\
0.3\end{array}$ \\
\hline カルシウム & $(\mathrm{mg} / \mathrm{dl})$ & $\begin{array}{l}M \\
\text { SD }\end{array}$ & $\begin{array}{l}9.9 \\
0.9\end{array}$ & $\begin{array}{r}10.0 \\
0.8\end{array}$ & $\begin{array}{l}9.9 \\
1.1\end{array}$ & $\begin{array}{l}9.6 \\
0.7\end{array}$ & $\begin{array}{l}9.6 \\
0.9\end{array}$ & $\begin{array}{r}10.2 \\
0.9\end{array}$ & $\begin{array}{r}10.1 \\
0.5\end{array}$ & $\begin{array}{l}9.9 \\
0.6\end{array}$ & $\begin{array}{l}9.7 \\
0.6\end{array}$ & $\begin{array}{r}10.0 \\
0.7\end{array}$ & $\begin{array}{r}10.1 \\
0.7\end{array}$ & $\begin{array}{r}10.1 \\
0.6\end{array}$ \\
\hline 無機リン & $(\mathrm{mg} / \mathrm{dl})$ & $\begin{array}{c}M \\
\mathrm{SD}\end{array}$ & $\begin{array}{l}4.8 \\
0.8\end{array}$ & $\begin{array}{l}5.5^{\mathrm{b})} \\
0.9\end{array}$ & $\begin{array}{l}4.8^{c)} \\
1.2\end{array}$ & $\begin{array}{l}5.7^{\mathrm{b})} \\
0.6\end{array}$ & $\begin{array}{l}4.6 \\
1.3\end{array}$ & $\begin{array}{l}5.0 \\
1.2\end{array}$ & $\begin{array}{l}4.9 \\
0.7\end{array}$ & $\begin{array}{l}5.5 \\
1.5\end{array}$ & $\begin{array}{l}4.7 \\
0.8\end{array}$ & $\begin{array}{l}4.9 \\
1.6\end{array}$ & $\begin{array}{l}4.9 \\
1.5\end{array}$ & $\begin{array}{l}5.8^{\mathrm{b})} \\
0.9\end{array}$ \\
\hline マグネシウム & $(\mathrm{mg} / \mathrm{dl})$ & $\begin{array}{l}\mathrm{M} \\
\mathrm{SD}\end{array}$ & $\begin{array}{l}2.4 \\
0.3\end{array}$ & $\begin{array}{l}2.5 \\
0.3\end{array}$ & $\begin{array}{l}2.4 \\
0.2\end{array}$ & $\begin{array}{l}2.4 \\
0.2\end{array}$ & $\begin{array}{l}2.4 \\
0.3\end{array}$ & $\begin{array}{l}2.2 \\
0.2\end{array}$ & $\begin{array}{l}2.5 \\
0.3\end{array}$ & $\begin{array}{l}2.4^{c)} \\
0.3\end{array}$ & $\begin{array}{l}2.6 \\
0.4\end{array}$ & $\begin{array}{l}2.7 \\
0.3\end{array}$ & $\begin{array}{l}2.7 \\
0.7\end{array}$ & $\begin{array}{l}2.4 \\
0.2\end{array}$ \\
\hline $\mathrm{AST}^{21}$ & $(\mathrm{IU} / \mathrm{L})$ & $\begin{array}{l}\mathrm{M} \\
\mathrm{SD}\end{array}$ & $\begin{array}{l}75 \\
32\end{array}$ & $\begin{array}{l}70 \\
14\end{array}$ & $\begin{array}{l}69 \\
17\end{array}$ & $\begin{array}{l}69 \\
16\end{array}$ & $\begin{array}{r}129 \\
71\end{array}$ & $\begin{array}{r}138 \\
66\end{array}$ & $\begin{array}{l}94 \\
20\end{array}$ & $\begin{array}{l}98^{c)} \\
26\end{array}$ & $\begin{array}{r}113 \\
31\end{array}$ & $\begin{array}{r}107 \\
25\end{array}$ & $\begin{array}{l}95^{\circ} \\
33\end{array}$ & $\begin{array}{l}83^{\mathrm{c})} \\
18\end{array}$ \\
\hline $\mathrm{GGT}^{31}$ & $(\mathrm{IU} / \mathrm{L})$ & $\begin{array}{c}\mathrm{M} \\
\mathrm{SD}\end{array}$ & $\begin{array}{r}15 \\
4\end{array}$ & $\begin{array}{r}13 \\
3\end{array}$ & $\begin{array}{r}14 \\
4\end{array}$ & $\begin{array}{r}13 \\
3\end{array}$ & $\begin{array}{r}19 \\
8\end{array}$ & $\begin{array}{l}18 \\
13\end{array}$ & $\begin{array}{r}15 \\
2\end{array}$ & $\begin{array}{r}15 \\
4\end{array}$ & $\begin{array}{r}22 \\
7\end{array}$ & $\begin{array}{c}14^{\mathrm{b})} \\
4\end{array}$ & $\begin{array}{r}16 \\
3\end{array}$ & $\begin{array}{r}17 \\
6\end{array}$ \\
\hline
\end{tabular}

${ }^{1)} \mathrm{GLU}$ 值 $(61 \mathrm{mg} / \mathrm{dl}) \cdot \mathrm{NEFA}$ 值 $(236 \mu \mathrm{Eq} / \mathrm{L})$ による区分：I 群 (低GLU・高NEFA)、II群（低GLU・低NEFA）、 III 群 (高GLU - 高NEFA)、IV 群 (高GLU - 低NEFA)

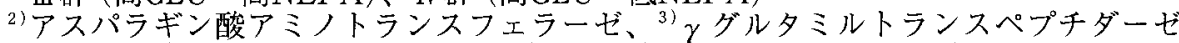

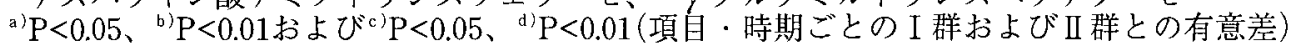

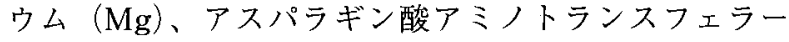
ゼ（AST）抽よ゙ $\gamma$ グルタミルトランスペプチダーゼ （GGT）を測定した。

統計処理：得られたデータは、実際の分婏日を基準と して分婏前 6-4 週 $(n=61)$ 、分娩前 $14-3$ 日（分婏前 $2-0$ 週: $n=92$ )、分娭後 2 週以内（分娭後 $0-2$ 週： $\mathrm{n}=49 ）$ および分娩後 $2-4$ 週 $(\mathrm{n}=39)$ に区分した。分 娩前 2-0 週、分娩後 $0-2$ 週抢よび $2-4$ 週における 全体と各群の血中成分の推移、各時期における全体の血 中成分間の相関を検討するとともに、各群から抽出した 39頭ではGLU、NEFA、ASTおよびGGTの推移を検討 した。データは平均土標準偏差で表現し、平均値の有意 性はStudentのt検定、相関係数と有意性についてNEFA とASTはPearson検定、他の項目はSpearman検定によ り行った。

\section{結 果}

（1）分婏前 2-0 週に抢ける血中成分

全体ではGLUが平均 $61 \mathrm{mg} / \mathrm{dl} 、 \mathrm{NEFA}$ は平均 $236 \mu \mathrm{Eq} / \mathrm{L}$ を示し、TCHOとBUN（相関係数；0.295, P<0.01）、
AST とGGT (0.268, P<0.01) およびTCHO (0.220. $\mathrm{P}<0.05)$ との間に正の相関が認められた。群別では GLUがI 群とII 群で向群やIV群に比べて低值、NEFA は I 群とIII群でII群や IV 群に比べて高值を、また、 TCHO、BUNおよびiPはI群でＩ群に比べて低值を示 した（表 1 )。

\section{（2）分娭後に打ける血中成分}

全体では分娩後 $0-2$ 週と $2-4$ 週に分娩前 $2-0$ 週 に比べてGLUが低值、NEFA、ASTおよびGGTは高值 を示した。また、分娩後 $0-2$ 週にはNEFAとAST (0.621，P<0.01）およびGGT (0.354, P<0.05) との間に 正の相関、分娩後 $2-4$ 週にはGLUとNEFA（-0.395, $\mathrm{P}<0.05)$ およびAST $(-0.501, \mathrm{P}<0.01)$ との間に負の 相関、NEFAとAST $(0.455, \mathrm{P}<0.01)$ との間に正の相 関が認められた。

群別では、GLUは分婏後 $0-2$ 週に各群間で差異が みられなかったが、分娩後 $2-4$ 週には分娩前 2-0 週 と同様、I 群と川群で向群やIV群に比べて低值、NEFA は分婏後 $0-2$ 週と $2-4$ 週にII群とI群でIV群に比べ て高值を示した（表 1、図 2)。また、ASTは分娩後 0 一- 

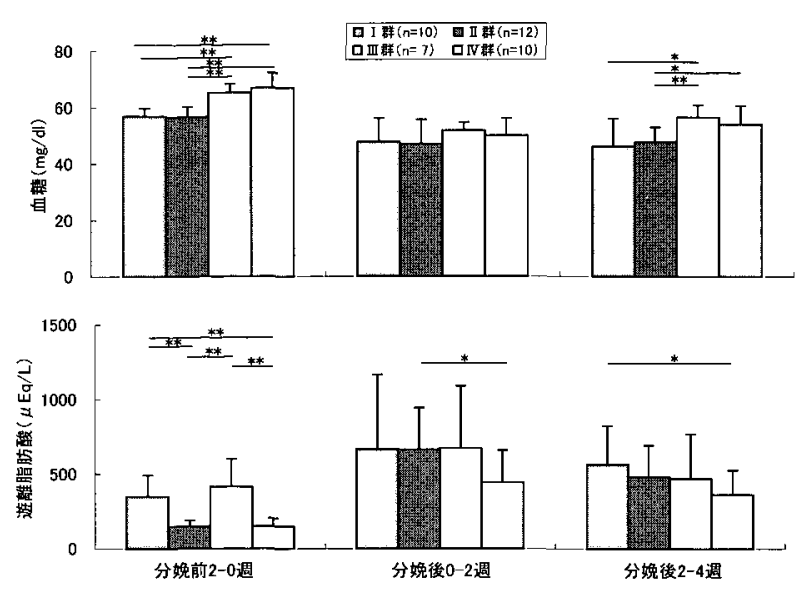

図2．健康乳牛の分娩前 $2-0$ 週における血糖および遊 離脂肪酸值別 "の血糖值と遊離脂肪酸值の推移

1) GLU值 $(61 \mathrm{mg} / \mathrm{dl})$ - NEFA值 $(236 \mu \mathrm{Eq} / \mathrm{L})$ による区分 : I 群 (低GLU・高NEFA)，II群(低GLU・低NEFA)， III 群 (高GLU - 高NEFA)，IV 群 (高GLU - 高NEFA)， $* \mathrm{P}<0.05, \quad * * \mathrm{P}<0.01$
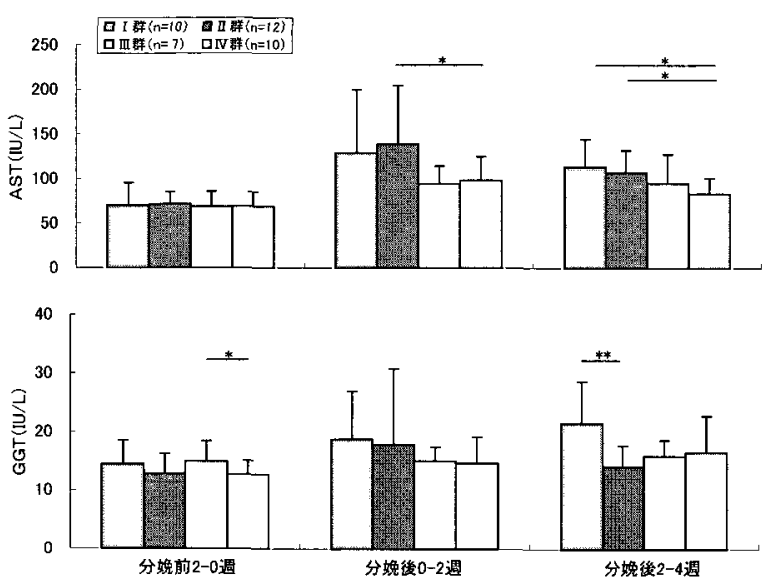

図 3. 健康乳牛の分婏前 $2-0$ 週における血糖および遊 離脂肪酸值別" フェラーゼ(AST) 值と y グルタミルトランスペプ チダーゼ(GGT)值の推移

") GLU值 $(61 \mathrm{mg} / \mathrm{dl})$ ・ NEFA值 $(236 \mu \mathrm{Eq} / \mathrm{L})$ による区分 : I 群 (低GLU・高NEFA), II 群 (低GLU・低NEFA), III群 (高 GLU • 高NEFA)，IV 群 (高GLU • 高NEFA), $* \mathrm{P}<0.05, \quad * * \mathrm{P}<0.01$

2 週と 2-4 週にII群で四群や IV 群に比べて、I群と I 群で V 群に比べて高值、GGTは分婏後 2-4 週にI 群 でI群に比べて高值を示した（表 1、図 3）。

\section{考 察}

乳牛の分娩時にはグルカゴンやグルココルチコイドの 上昇のためにGLUが高值を示し、また、ホルモン変化 や分娩ストレスのためにNEFAが上昇する [9]。今回、 分婏による影響を排除するために分婏前 2 日以内の乳牛 を除外し、分婏前 14 3日（2-0 週）のGLU值と NEFA值によって供試牛を 4 群に区分した。I 群は低工 ネルギーで体脂肪が動員されている状態、【群は低工ネ
ルギーであるが体脂肪が動員されていない状態、向群は エネルギーが充足されているが体脂肪が動員されている 状態、IV群はエネルギーが充足された状態と考えた。し かし、GLUとNEFAの平均值 $(61 \mathrm{mg} / \mathrm{dl}$ と $236 \mu \mathrm{Eq} / \mathrm{L})$ は、いずれも正常值 [12］の範囲であり、エネルギー状 態を判定する基準としては必ずしも適切でないと考えら れる。また、II 群とIII群の病態についてはボデイコンデ イション・スコア（BCS）の推移や詳細な糖代謝検查所 見を娭討していないので、体脂肪の不足や過剩あるいは 糖代謝の異常に起因したものか不明である。今回、分娩 後のNEBとの関係を検討するために 4 群に区分したが、 分娩前のGLUとNEFAの平均值を基準とした群分けの 妥当性については検討の余地がある。

妊娠末期における乾物摂取量の低下は子宮拡大による 第一胃運動の障害や分娩前後のホルモン変化、特に血中 エストロジェンの増加とプロジェステロンの減少が関与. している [8]。エネルギーの摂取量が要求量より少な い場合、乾乳期でも体脂肪が動員されてNEFAが上昇す る $[2 ， 6 ， 9]$ 。妊張末期において GLUは $65 \mathrm{mg} / \mathrm{dl}$ 、 NEFAは170〜 $190 \mu \mathrm{Eq} / \mathrm{L} か ゙$ 正常值 [12]、また、NEFA は $400 \mu \mathrm{Eq} / \mathrm{L}$ 以下が適正值 [17］とされている。今回、 分娭前 2-0 週においてGLUが $60 \mathrm{mg} / \mathrm{dl}$ 以下は 92 頭中 46 頭 $(50 \%) 、 \mathrm{NEFAが} 400 \mu \mathrm{Eq} / \mathrm{L}$ 以上は11頭（12\%)、ま た、GLUが $60 \mathrm{mg} / \mathrm{dl}$ 以下でNEFAが $400 \mu \mathrm{Eq} / \mathrm{L}$ 以上を示 すものはI群の23頭中 6 頭で認められた。このことから、 分婏前㣪に臨床的異常がみられない健康牛の一部は、分 娩前 2-0 週にNEB状態にあることが確認された。分 娩前 2-0 週にはTCHOとBUN、ASTとTCHOとの間 に正の相関が認められ、また、I 群では】群に比べて TCHOやBUNが低值を示したことから、分娩前におけ るNEFAの高值は、肝機能の低下やタンパク摂取の不足 とも関連があると考えられた。しかし、分婏前における $\mathrm{NEB} の$ 要因については、乳牛の飼養管理状況や乾物掑 取量、出生子牛の体重との関連を含めて、さらに検討寸 る必要がある。

分婏後におけるNEBは移行期の乾物摂取量低下 [13] や分娩後の泌乳開始および急激な泌乳量増加と関連があ る。泌乳開始や泌乳量増加によってエネルギー要求量が 急激に増加し、NEFAが上昇するとともに重篤なエネル ギー不足のためにGLUが低下する [9]。今回、分婏後 には全体および各群とも分娭後 1 力月以内の正常値 (GLU ; 58 59mg/dl、NEFA ; 235 400 $\mu \mathrm{Eq} / \mathrm{L}$ ) [12] に比べてGLUが低值、NEFAが高值傾向を示したこと から、明らかなNEB状態にあると考えられた。分娩後 
のNEBは乾物䝮取量、泌乳量や泌乳の增加速度と関連 があると推察されるが、今回これらの関係は検討してい ない。一方、GLUとNEFAは分婏前 $2-0$ 週と分婏後 $2-4$ 週との間で有意な相関がみられなかったが、分婏 後 2-4 週にGLUは分婏前 2-0 週に低值であった群 で低值、NEFAは分娭前 $2-0$ 週に高值であった群で高 值を示す傾向が認められた。このことから、分婏後 24 週のNEBは分婏前 $2-0$ 週のNEBと密接な関連のあ ることが示唆された。分婏前のNEBは、分婏時に乾物 掑取量低下や泌乳開始によって急激に悪化するが、分娩 後もNEB傾向が持続して分婏後 $2-4$ 週に分婏前と同 様の傾向を示したものと推察した。なお、分娩後 $0-2$ 週には分婏前 2-0 週のNEBと一定の関係がみられな かったが、これは分婏後 $0-2$ 週に各群とも分娩前の值 にかかわらずGLUが著しく低下し、NEFAが著しく上 昇したことによると考えられた。

NEB牛に扔いて肝臟はグルコースとケトン体の産生、 エネルギー産生のための血中からのNEFA取り込みなど 重要な機能を果たしている [10］。今回、分婏後にGLU とASTとの間に負の相関、NEFAとASTおよびGGTと の間に正の相関が、また、分婏後には分婏前 $2-0$ 週に GLUが低值であった群でASTが高值、分婏前 2-0 週 にGLUが低值でNEFAが高值であった群でGGTが高値 を示す傾向が認められた。これらのことから、分娩後の NEBは肝機能と密接な関連があり、分婏後の肝機能は 分婏前のNEBとも関連のあることが示唆された。分婏 前後における肝機能の低下は脂肪肝と関連 $[3,6,10$, 11〕があり、脂肪肝牛では肝蔵にトリグリ七ライドが蓄 積してASTやGGTの上昇のほか、種々の肝機能異常を 呈する $[3,11]$ 。今回の供試牛に極端な過肥牛は含ま れていないが、BCSに異常がみられない乳牛でも分娭前 後に脂肪肝に宿る可能性がある。また、移行期の急激な 濃厚飼料の增給や高タンパク飼料の過給は、ルーメンコ ンデイションの低下と内因性エンドトキシンの増加を招 き、肝機能低下の要因になると考えられる。分婏後の NEBと関連した肝機能低下の要因については、ASTや GGT以外の血清酵素および他の肝機能検查を含めて、 さらに検討する必要がある。

最近、乳牛の泌乳量が飛躍的に増加し、これに伴って NEB抢よびNEB関連疾病が多発していることから、乳 牛の飼養管理では、分娭後のNEB対策 $[4,5,7,15]$ が重要な課題となっている。今回、分娩後のNEBは分 娩前のNEBおよび肝機能と密接な関連のあることが示 唆されたことから、今後、乾乳期あるいは移行期のエネ
ルギー不足や乾物掑取量低下を最小限にする対策ととも に、分婏前後の肝機能低下を軽減する対策を考慮する必 要があると考えられた。

\section{文 献}

1. Bell,A.W., Slepetis,R. and Ehrhardt,R.A. (1995). Growth and accretion of energy and protein in the gravid uterus during late pregnancy in Holstein cows. J. Dairy Sci. 78: 1954-1961.

2. Bertics, S. J., Grummer, R. R., Cadorniga-Valino, C. and Stoddard, E. E. (1992). Effect of prepartum dry matter intake on liver triglyceride concentration and early lactation. J. Dairy Sci. 75: 1914-1922.

3. Bobe, G., Young, J. W. and Beitz, D. C. (2004). Pathology, etiology, prevention and treatment of fatty liver in dairy cows. J. Dairy Sci. 87: 3105-3124.

4. Duffield,T. Bagg, R. DesCoteaux,L. Bouchard,E. Brodeur,M. DuTremblay,D. Keefe,G. LeBlanc,S. and Dick,P. (2002). Prepartum monensin for the reduction of energy associated disease in postpartum dairy cows. J. Dairy Sci. 85: 397-405.

5. Formigoni,A. Cornil,M.-C. Prandi,A. Mordenti,A. Rossi,A. Portetelle,D. and Renaville,R.B. (1996). Effect of propylene glycol supplementation around parturition on milk yield, reproduction performance and some hormonal and metabolic characteristics in dairy cows. J. Dairy Res. 63: 11-24.

6. Gerloff, B.J. (2000). Dry cow management for the prevention of ketosis and fatty liver in dairy cows. Vet. Clin. North. Am. 16: 283-292.

7 . Green,B.L. McBride,B.W. Sandals,D. Leslie,K.E. Bagg,R. and Dick,P. (1999). The impact of a monensin controlled-release capsule on subclinical ketosis in the transition dairy cows. J. Dairy Sci. 82: 333-342.

8. Grummer,R.R., Bertics,S.J., Lacount,D.W., Snow,J.A., Dentine,M.R. and Stauffacher,R.H. (1990). Estrogen induction of fatty liver in dairy cattle. J. Dairy Sci. 73: $1537-1543$.

9. Grummer,R.R. (1995). Impact of changes in organic nutrient metabolism on feeding the transition dairy cow. J. Anim. Sci., 73: 2820-2833.

10. Herdt,T.H. (2000). Ruminant adaptation to negative energy balance: Influences on the etiology of 
ketosis and fatty liver. Vet. Clin. North. Am. 16: 215-230.

11. Katoh,N. (2002). Relevance of apolipoproteins in the development of fatty liver and fatty liverrelated peripartum diseases in dairy cows. J. Vet. Med. Sci. 64: 293-307.

12. Kida, K. (2002). Use of every ten-day criteria for metabolic profile test after calving and dry off in dairy herds. J. Vet. Med. Sci. 64: 1003-1010.

13. 西田武弘, 栗原光規, 寺田文典, Purnomoadi,A. 柴 田正貴 (1999). 飼料の粗濃比が妊娠末期の乾乳牛の 乾物摂取量に及はすす影響. Anim. Sci. J. 70: J114-J118.

14. 西田武弘, 栗原光規, 寺田文典, Purnomoadi,A. 柴 田正貴 (1999). 乳牛の妊娠末期におけるエネルギー 水準が血漿代謝産物およびホルモン濃度に及ほす影響. Anim. Sci. J. 70: J123-J131.

15. Pickett,M.M., Piepenbrink,M.S. and Overton,T.R. (2003). Effects of propylene glycol or fat drench on plasma metabolites, liver composition, and producyion of dairy cows during the periparturient period. J. Dairy Sci. 86: 2113-2121.

16. 佐藤 繁, 小野秀弥, 植松正巳, 畠山直一郎, 角田元 成（2003）。周産期疾患の発症乳牛に㧍ける乾乳期の 血中成分. 家畜臨床誌 26:1-26.

17. Vandehaar,M.J., Yousif,G., Sharma,B.K., Herdt,T.H., Emery, R. S., Allen, M.S. and Liesman, J.S. (1999). Effect of energy and protein density of prepartum diets on fat and protein metabolism of dairy cattle in the periparturient period. J. Dairy Sci. 82: 12821295. 